\section{Development of technology-based firms of the Vale do Paraíba Paulista region: survey with incubators managers and incubated companies}

\author{
Desenvolvimento de empresas de base tecnológica da região do \\ Vale do Paraíba Paulista: pesquisa com gestores de incubadoras \\ e empresas incubadas
}

GESTÃO PRODUCÃ̃O

ISSN 0104-530X (Print) ISSN 1806-9649 (Online)

\author{
Walter Saraiva Lopes ${ }^{1}$ (i) \\ Renato José Sassi ${ }^{2}$
}

\begin{abstract}
How to cite: Lopes, W. S., \& Sassi, R. J. (2019). Development of technology-based firms of the Vale do Paraíba Paulista region: survey with incubators managers and incubated companies. Gestão \& Produção, 26(4), e1302. https://doi.org/10.1590/0104-530X1302-19
\end{abstract}

\begin{abstract}
Technology-based firms are small businesses that are characterized by being related to innovation and technological development in production and services. These companies for a period of time receive support calls based Technology-based incubators. The objective of this study was to analyze the degree of importance perceived by managers of Technology-based firms and managers of Technology-based incubators of the factors that contribute to the development of Technology-based firms of the Vale do Paraiba Paulista Region. The following factors were analyzed: entrepreneurial characteristics, resources offered by Technology-based incubators, features offered in partnership with other development agents and selection requirements of Technology-based incubators by the Technology-based firms. One for the five managers of the Technology-based incubators and the other for twenty-five managers of Technology-based firms. For this, a survey in June 2011 was applied and two questionnaires divided into four parts was performed. The Vale do Paraíba Paulista Region was chosen to concentrate an important Industrial and Technological Pole, which stands out by strong economic growth, located between the axis of two major Brazilian cities, Rio de Janeiro and São Paulo. The completion of the work enabled visualize how technology-based entrepreneurship has been practiced in the region Vale do Paraíba Paulista present important information in the region in 2011. It also allowed me to analyze the perception of managers regarding the factors considered.
\end{abstract}

Keywords: Technology-based incubators; Technology-based firms; Contributing factors; Vale do Paraíba Paulista.

Resumo: Empresas ou incubadas de Base Tecnológica (EBTs) são pequenas organizações que se caracterizam por estarem relacionadas ao processo de inovação e desenvolvimento tecnológico na produção de novos produtos e serviços. Essas empresas, por um determinado periodo de tempo, recebem o apoio das chamadas Incubadoras de Base Tecnológica (IBTs), o que influencia no seu desenvolvimento. Este trabalho teve como objetivo analisar o grau de importância, percebido pelos gestores de IBTs e de EBTs, dos fatores que contribuem para o desenvolvimento das Empresas de Base Tecnológica da região do Vale do Paraíba Paulista. São eles: características empreendedoras, recursos oferecidos pelas IBTs, recursos oferecidos em parcerias com outros agentes de desenvolvimento e requisitos de seleção de EBTS, por parte das IBTS. Para tanto, foi realizada, em junho de 2011, uma pesquisa por meio da aplicação de dois questionários, divididos em quatro partes: um aplicado para cinco gestores de IBTS e outro para vinte e cinco gestores de EBTs. A região do Vale do Paraíba Paulista (VPP) foi escolhida por concentrar um importante Polo Industrial e Tecnológico, que se destaca pelo forte crescimento econômico, localizado entre o eixo das duas principais metrópoles brasileiras, Rio de Janeiro e São Paulo. De modo geral, este estudo possibilitou analisar a percepção dos gestores de IBTs e EBTs com relação aos fatores considerados importantes para o seu desenvolvimento e também verificar como o empreendedorismo de base tecnológica foi praticado na região do VPP.

Palavras-chave: Incubadoras de base tecnológica; Empresas de base tecnológica; Fatores de contribuição; Vale do Paraíba Paulista.

\footnotetext{
Centro de Ciências Sociais, Saúde e Tecnologia, Universidade Federal do Maranhão - UFMA, Rua Urbano Santos, s/n, Centro, CEP 65900-410, Imperatriz, MA, Brasil, e-mail: w.saraiva@yahoo.com.br

${ }^{2}$ Programa de Pós-graduação em Informática e Gestão do Conhecimento, Universidade Nove de Julho - UNINOVE, Rua Vergueiro, 235/249, Liberdade, CEP 01504-001, São Paulo, SP, Brasil, e-mail: sassi@uni9.pro.br
}

Received Feb. 28, 2014 - Accepted Apr. 2, 2015

Financial support: Universidade Nove de Julho. 


\section{Introduction}

Considered as the basic production units, companies produce and offer goods and services, as demanded by modern society and can be classified within the limits set as large, medium, small and micro enterprises (Silva et al., 2005; Zica \& Martins, 2008).

According to SEBRAE (2006), small companies differ due to the small number of employees and the small annual gross revenue, making it possible to benefit from the benefits and incentives provided by the legislation.

The dynamics of the economy, growth and market demands mean that small companies need mechanisms to assist in their development, based on managerial and technological knowledge, leading to their strengthening and expansion (Pereira et al., 2009).

Thus, small companies seek support for the development of their business activities in institutions linked to small entrepreneurs, such as the Brazilian Micro and Small Business Support Service (SEBRAE), employers' unions, business incubators, universities, etc.

In the case of business incubators, these are organizations that can be linked to public or private educational institutions, prefectures, and even independent business initiatives, where the basis for sustaining an incubation program is based on the diffusion of the entrepreneurial culture, knowledge and innovation.

The company incubator is useful to stimulate the emergence and consolidation of small businesses, generally called incubated, which, supported by a physical space with technical and operational infrastructure, may have the innovative ideas of future entrepreneurs transformed into new products or processes (Porton \& Longary, 2005).

According to data presented by the National Association of Entities Promoting Innovative Enterprises (ANPROTEC, 2010), the average survival rate of organizations generated in business incubators is $82 \%$. In the case of companies that did not go through this incubation process, only $40 \%$ survived for more than four years in the market. In this way, business incubators have gained strength and credibility.

The ANPROTEC Panorama Survey 2010 shows the number of business incubators in Brazil with significant growth, according to Figure 1.

According to Melo \& Leitão (2010), the incubators can be classified in types or according to the businesses incubated:

Technological Base: receives technology-based companies, responsible for some type of innovation in products, processes, components or accessories;

- Traditional: it accepts companies from the traditional sectors;

- Mixed: it houses technology-based companies and traditional sectors;

- Agribusiness: focused on the development of production/technology in the agricultural sector;

- Cultural: it houses projects in the cultural area, promoting the process of entrepreneurship of cultural products and services;

- Arts: supports creative and enterprising people who intend to develop an innovative business in the field of arts;

- Cooperative: supports cooperatives in the process of formation and/or consolidation, installed inside or outside the municipality;

- Social: houses projects from social projects, linked to the traditional sectors and whose knowledge is in the public domain, which meet the demand for job creation, income and improvement of community living conditions;

- Virtual: established through internet, has a large database and computer science, aiming to stimulate new business.

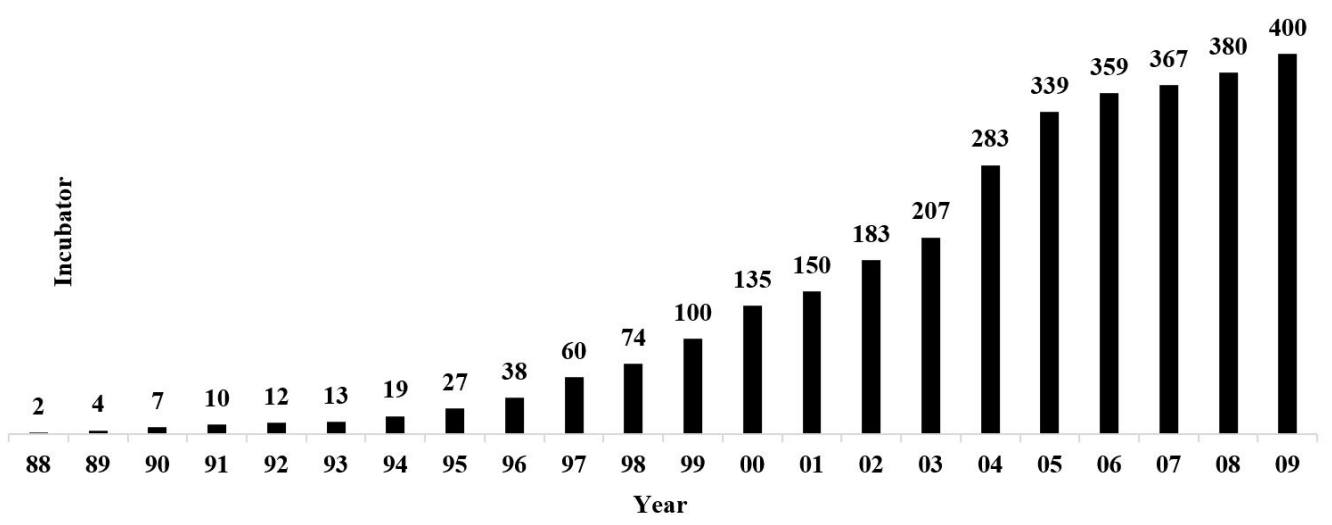

Figure 1. Evolution of business incubators in Brazil (1988 - 2009). Source: Adapted from ANPROTEC (2010). 


\section{Theoretical foundation}

\subsection{The relationship between incubators and companies based on technology}

In the attempt to introduce knowledge and to empower new entrepreneurs, the Technological Base Incubators (TBIs) host and incubate nascent companies, whose productive processes employ innovative technologies and scientific knowledge (Stainsack, 2003; Toledo et al., 2008). These nascent companies, which go through this incubation process, are called Technological Base Firms (TBFs), Technologically Based Incubated or Incubated Companies.

TBFs are characterized in two ways: (i) process or production, which results from scientific research, whose added value comes from technological innovations; and (ii) application of scientific knowledge, the mastery of complex techniques and high technical quality work (ANPROTEC, 2002). Table 1 shows some of the main characteristics of the TBFs.

Through the TBIs, it is possible to support these new ventures of innovative projects, based on the offer of innumerable facilities and support to entrepreneurs, such as: specialized consultancies, managerial skills and qualifications, physical space and operational, administrative and technical infrastructure, support of infrastructure, among others, for a certain period (Cooper \& Park, 2008; Paletta, 2008; Torkomian \& Piekarski, 2008).

The TBI must also have shared services, advise and train the entrepreneurs of the TBFs in the technical and managerial questions, as well as to monitor and evaluate the performance of the incubated companies (Pinho et al., 2002; Stainsack, 2003).

According to Paletta (2008), the main objectives of an TBI are:

- Promote a mechanism of university-businessgovernment integration, broadening and diffusing the entrepreneurial culture in the academic environment;

- Promote the training of entrepreneurs in incubated ventures;
- Ensure that new products and services resulting from basic and technological research can reach the consumer market;

- Contribute to regional development through business creation and income generation;

- Provide opportunities for academics and entrepreneurs to transform ideas into products, processes and services, based on innovative technologies, and have access to an enterprise support infrastructure;

- To strengthen the companies in the initial or embryonic stage, emphasizing the formation of the entrepreneur, the maturing of the project and the structuring of the business;

- Enable entrepreneurs to use services, infrastructure and physical space, under established obligations and conditions;

- Facilitate access to technological and managerial innovations.

By reaching the main objectives highlighted above, an TBI is contributing to the reduction of TBFs mortality, regional development, creating skilled jobs, and increasing employment (Remiro et al., 2008).

The performance of the TBI during the incubation process is fundamental, as the difficulties faced by the TBFs are diverse. A study conducted by Raupp \& Beuren (2009), points out several difficulties faced by Brazilian TBFs, which can be visualized in Figure 2.

The scenario of TBFs in Brazil can be verified in more detail in Santos \& Pinho (2010).

\subsubsection{Entrepreneurship in TBIs and TBFs}

Entrepreneurship is one of the most significant critical success factors for economic development and for the generation of income and wealth for nations and companies, which has resulted in the creation of several programs and bodies to support entrepreneurship practice.

Table 1. Main characteristics of TBFs.

\begin{tabular}{ll}
\hline \multicolumn{1}{c}{ Authors } & Characteristics \\
\hline Toledo et al. (2008) & Tecnologic innovation; \\
& - Systematic application of technical-scientific knowledge; \\
& - Acting in niche market. \\
Torkomian \& Piekarski (2008) & - Innovation process; \\
& - Technological development. \\
Berté e Almeida (2006) & Ensuring innovation requires high-level human resources; \\
& • Stimulate continuing education. \\
Filion (1999) & The entrepreneur is the key person in the operation of the company, because \\
& it is he who creates and develops the business vision with conviction, \\
& towards a goal. \\
\hline
\end{tabular}




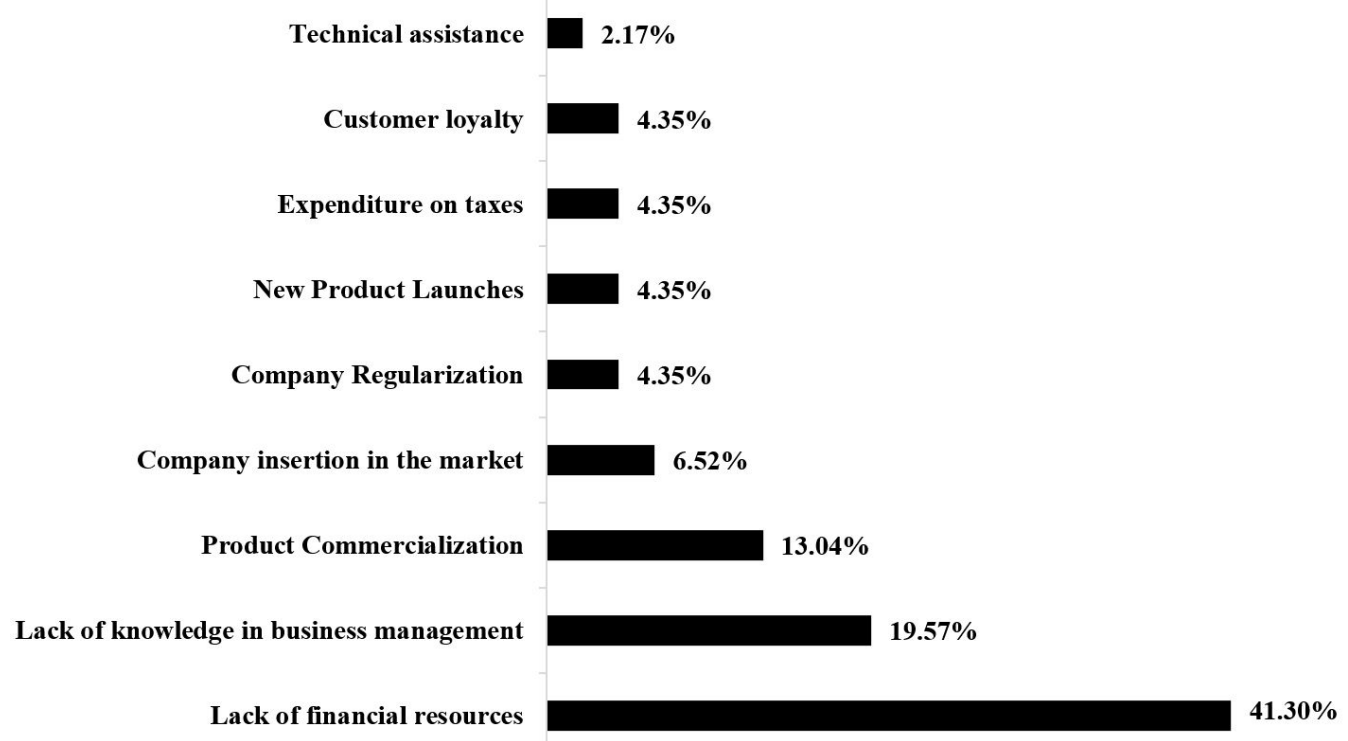

Figure 2. Difficulties encountered by Brazilian TBFs during the incubation period. Source: Raupp \& Beuren (2009).

The incubators of companies, including the TBIs, aim to generate an environment conducive to the development of entrepreneurial actions, by encouraging innovation, acting in support of new entrepreneurs, usually in a subsidized way (Macêdo et al., 2009).

Incubations, including TBFs, are not always prepared for the effects of increased competitiveness and are rarely managed by people with experience or training to perform this function. In addition, they have a very simple business structure, when compared to large companies that represent an important segment within the market (Raupp \& Beuren, 2009).

According to Stainsack (2003), the TBFs depend on entrepreneurs, who in turn seek support for the growth of their businesses in the initial phase. One of the mechanisms used by TBI managers is through administrative, technological and infrastructure support, made available to the TBFs during the incubation process.

One of the advantages of incubators in encouraging entrepreneurship is to make it an outstanding activity that promotes entrepreneurial motivations and entrepreneurial actions necessary to develop their original idea in order to achieve success. To succeed in the venture, during incubation time, companies need to overcome the challenge of developing an idea in economically viable products.

The entrepreneurial action is the result of an innovative idealization that was created or implemented by someone inserted in the business world, from the visualization of an opportunity, that is, by a person who sought personal fulfillment and recognition on the part of its members (Macêdo et al., 2009).

\subsection{Vale do Paraíba Paulista region}

The region of Vale do Paraíba Paulista (VPP) was chosen because it concentrates an important Industrial and Technological Pole, which stands out for the strong economic growth, located between the axis of the two main Brazilian metropolises, Rio de Janeiro and São Paulo. The region had in March 2011, the year in which the data was collected, six TBIs and forty-eight TBFs, which were part of the productive arrangement of the site.

Located in the east of the state of São Paulo, the VPP, which is on the border of the Paraíba do Sul river basin, had a census population of 2,258,956 inhabitants (IBGE, 2011) distributed in 39 cities in 2009. the most important ones: São José dos Campos, Taubaté, Jacaré, Guaratinguetá, Lorena and Pindamonhangaba (Vale do Paraíba Paulista, 2012). In Figure 3, the location of the Vale do Paraíba Paulista region in the state of São Paulo is illustrated below.

The process of industrialization in the region was boosted by the inauguration of the Presidente Dutra Highway in the early 1950s, which enabled a connection between the cities of São Paulo and Rio de Janeiro.

This factor allowed the region to develop an important industrial park, with emphasis on the automotive (Ford, Volkswagen, General Motors), aeronautics and aerospace sectors (Embraer, Aerospace Technology General Command, National Institute for Space Research), petrochemical (Petrobrás), among others.

The objective of this study was to analyze the degree of importance perceived by the managers 


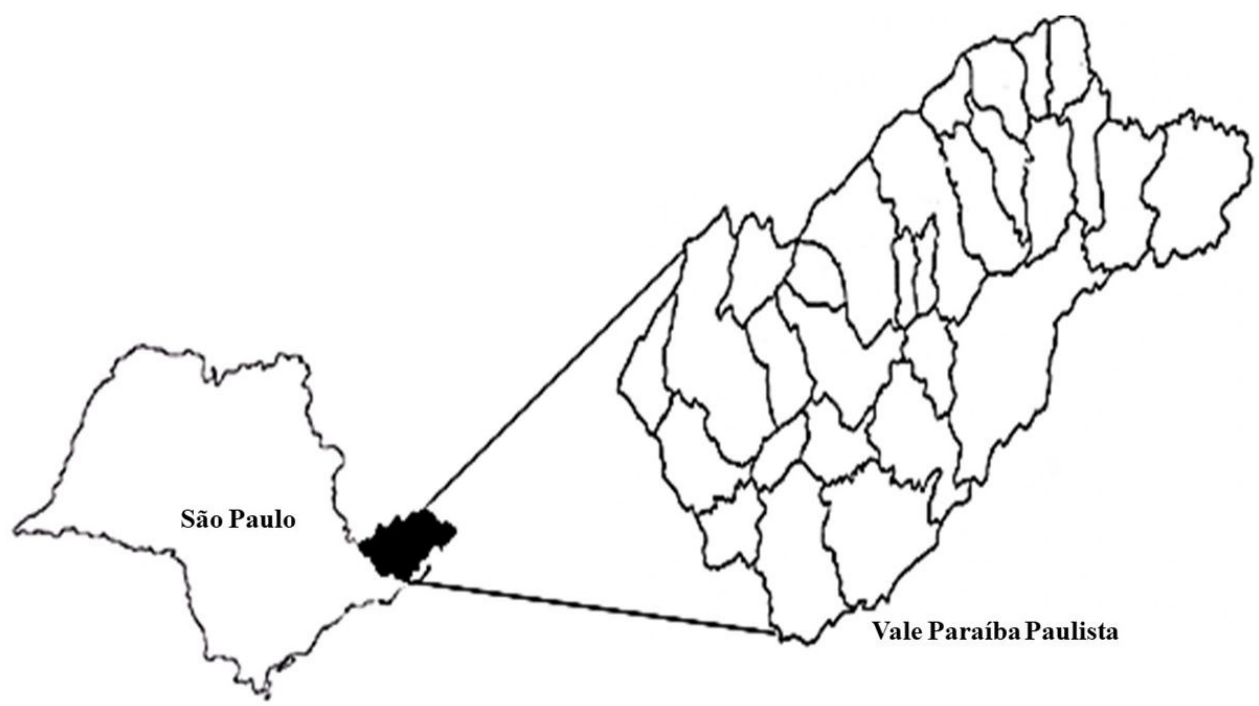

Figure 3. Location of the Vale do Paraíba Paulista region in the state of São Paulo.

of TBIs and TBFs of the factors that contribute to the development of Technologically Based Firms in the Vale do Paraíba Paulista region. These are: entrepreneurial characteristics; resources offered by TBIs; resources offered in partnerships with other development agents and requirements for selection of TBFs by TBIs.

\section{Material and methods}

The research methodology adopted in this study was defined as bibliographical and exploratory. The research was based on published material, mainly composed of books, periodicals and material made available on the Internet.

According to Gil (2002), an exploratory research aims to provide greater familiarity with the problem, making it explicit or helping in the construction of hypotheses. In most cases it involves interviews with people who have had practical experiences with the problem researched and analyzes of examples that stimulate understanding. It can be said that this research aims at the improvement of ideas or the discovery of intuitions, which makes its planning very flexible, considering the most varied aspects related to the fact studied.

According to Yin (2006), the exploratory research also allows a greater familiarity between the researcher and the researched subject, since this is still little known or little explored. In this sense, if the proposed problem does not present aspects that allow the visualization of the procedures to be adopted, it will be necessary for the researcher to initiate a probing process, in order to improve ideas, to discover intuitions and, later, to construct hypotheses.

\subsection{Listing of TBIs and TBFs information}

The survey carried out in March 2011 by the authors of this study showed that there were seven incubators and sixty-two incubated companies in the VPP region, related to their partners (companies that support incubator activities) is shown in Table 2.

Of the seven incubators, the incubator Jacareí, with 14 incubated companies, did not incubate TBF, that is, it was not an TBI, reason why it was not considered in this work, thus reducing the number of participating incubators to 6 (TBIs) and the number of incubated (TBFs) for forty-eight (62-14).

After three months, that is, between the survey period, in March 2011, until the application of the two questionnaires, in June of the same year, ten TBFs graduated, that is, their incubation period was finalized. Thus, the number of TBFs was reduced, again, from forty-eight to thirty-eight.

Table 3 shows the TBIs (six) and TBFs (thirty-eight), which were invited to participate in the survey, held in June 2011.

The TBIs and TBFs, invited to participate in this research, had the option to respond to the questionnaires by email, telephone or in person. REVAP claimed at the time to be in the process of restructuring and did not respond to the questionnaire, but authorized the research to be carried out with its TBFs. Thus, the percentage of participation was:

- Of the six invited TBIs, five answered the questionnaire (83.33\%);

- Of the thirty-eight invited TBFs, twenty-five answered the questionnaire $(66 \%)$. 
Table 2. Number of incubators and incubators in the VPP region in March 2011.

\begin{tabular}{cllc}
\hline NUMBER & \multicolumn{1}{c}{ INCUBATORS } & \multicolumn{1}{c}{ PARTNERS } & $\begin{array}{c}\text { INCUBATED } \\
\text { COMPANIES }\end{array}$ \\
\hline 1 & UNIVAP & Universidade do Vale do Paraíba & 4 \\
2 & REVAP & $\begin{array}{l}\text { Refinaria Henrique Lage (Petrobrás REVAP e } \\
\text { Universidade do Vale do Paraíba) }\end{array}$ & 12 \\
& & Comando-Geral de Tecnologia Aeroespacial & 10 \\
3 & INCUBAERO & Prefeitura de São José dos Campos & 12 \\
4 & INCUBADORA DE NEGÓCIOS & 14 \\
5 & JACAREÍ & Prefeitura de Jacareí & 6 \\
6 & INNOVATORE & SEBRAE de Pindamonhangaba & 4 \\
7 & INOVE & Prefeitura e Associação Comercial de & \\
& Guaratinguetá & $\mathbf{6 2}$ \\
\hline
\end{tabular}

Table 4 shows the TBIs (five) and the TBFs (twenty-five) that answered the questionnaire, composing the research sample.

Certain characteristics of the TBIs and, consequently, of the TBFs participating in the research are important. For this reason, a small introductory questionnaire was applied to TBI managers with the following questions:

1) In what year was your incubator set up?

2) Is the incubator able to incubate how many companies?

3) How many companies are incubated at the moment?

4) What is the percentage of survival of the companies during the incubation period?

5) What is the survival rate of companies after graduating in five years?

6) How do you evaluate the performance of your incubator? Justify.

The results are presented below in Tables 5, 6,7 and 8 .

The five participating TBIs were considered new with respect to the year of their creation, the oldest TBI was 14 years old (Table 5).

The maximum capacity that each TBI had of incubation and the number of TBFs incubated during the realization of this research are shown in Table 6.

Table 7 shows the percentage of survival of the TBFs during the incubation period and the percentage of survival in the market, after being graduated in the period of five years.

It can be seen in Table 7 , for example, that $70 \%$ of the TBFs incubated in the INOVE incubator survived the incubation period and the 5-year graduation period. Table 8 shows the time (in months) that TBFs have to incubate, based on 24 responses, since only one TBF did not respond.
Table 3. Invited TBIs and TBFs.

\begin{tabular}{clc}
\hline & \multicolumn{1}{c}{ TBIs } & TBFs \\
\hline 1 & UNIVAP & 4 \\
2 & REVAP & 4 \\
3 & INCUBAERO & 8 \\
4 & INCUBADORA DE NEGÓCIOS & 12 \\
5 & INNOVATORE & 6 \\
6 & INOVE & 4 \\
& Total & $\mathbf{3 8}$ \\
\hline
\end{tabular}

Table 4. TBIs and TBFs that answered the questionnaire, composing the research sample.

\begin{tabular}{lcc}
\hline \multicolumn{1}{c}{ INCUBATORS } & TBIs & TBFs \\
\hline UNIVAP & Yes & 2 \\
REVAP & No & 4 \\
INCUBAERO & Yes & 2 \\
INCUBADORA DE NEGÓCIOS & Yes & 10 \\
INNOVATORE & Yes & 4 \\
INOVE & Yes & 3 \\
Total & $\mathbf{5}$ & $\mathbf{2 5}$ \\
\hline
\end{tabular}

Table 5. Age of TBIs.

\begin{tabular}{lcc}
\hline \multicolumn{1}{c}{ INCUBATOR } & $\begin{array}{c}\text { YEAR OF } \\
\text { CREATION }\end{array}$ & AGE \\
\hline INCUBAERO & 2004 & 7 \\
INNOVATORE & 2007 & 4 \\
INOVE & 2006 & 5 \\
NEGÓCIOS & 2004 & 7 \\
UNIVAP & 1997 & 14 \\
\hline
\end{tabular}

Table 6. Capacity and number of TBFs incubated in TBIs (June 2011).

\begin{tabular}{lcc}
\hline \multicolumn{1}{c}{ INCUBATOR } & CAPACITY & INCUBATED \\
\hline INCUBAERO & 10 & 8 \\
INNOVATORE & 10 & 6 \\
INOVE & 20 & 4 \\
NEGÓCIOS & 15 & 12 \\
REVAP* & 10 & 4 \\
UNIVAP & 10 & 4 \\
\hline
\end{tabular}

*The REVAP data in this table was obtained by telephone. 


\subsection{Questionnaires}

Two questionnaires, divided into four parts, were applied to managers of TBIs and TBFs. To exemplify, the questionnaire applied is found in the Appendix A of this paper. The questionnaires considered the degree of importance given to the following factors:

- Entrepreneurial characteristics (part 1);

- The resources offered by TBIs (part 2);

- Resources offered in partnerships with other development actors (part 3);

- The requirements for selection of TBFs by the TBIs (part 4).

The Likert Scale was used, in which the degree of importance attributed to each contribution factor was indicated, as can be seen in Table 9, below. The Likert Scale is a type of psychometric response scale commonly used in questionnaires and opinion surveys. When responding to a questionnaire, based on this scale, participants specify their level of agreement with a statement (Likert, 1932).

Based on the responses of the questionnaires, eight Tables 10 to 17 were developed, in which the degree of importance attributed by the managers of TBIs and TBFs to the factors considered, and the number of respondents are presented. The data obtained through the questionnaire responses were analyzed using Microsoft Excel software.

\section{Presentation and discussion of results}

Tables 10 to 13 show the degree of importance attributed by TBIs managers to the factors considered, and the number of respondents. Among the Tables 14 to 17, we present the degree of importance attributed by the TBFs managers to the factors considered, and the number of respondents.

Table 7. Percentage of survival in the incubation period and graduation in the period of five years.

\begin{tabular}{lccccc}
\hline & INOVE & UNIVAP & NEGÓCIOS & INCUBAERO & INNOVATORE \\
\hline Incubation Period & $70 \%$ & $90 \%$ & $100 \%$ & $100 \%$ & $100 \%$ \\
Graduation Period & $70 \%$ & $100 \%$ & $80 \%$ & $100 \%$ & $100 \%$ \\
\hline
\end{tabular}

Table 8. TBFs incubation time in months.

\begin{tabular}{lccccc}
\hline Incubation time in months & Till $\mathbf{1 2}$ & $\mathbf{1 3}$ to $\mathbf{2 4 5}$ & $\mathbf{2 5}$ to $\mathbf{3 6}$ & $\mathbf{3 7}$ to $\mathbf{4 8}$ & Above $\mathbf{4 9}$ \\
\hline Number of TBFs & 5 & 9 & 1 & 8 & 1 \\
\hline
\end{tabular}

Table 9. Likert scale to determine the degree of importance attributed to contribution factors.

\begin{tabular}{ccccc}
\hline \multicolumn{5}{c}{ IMPORTANCE ATTRIBUTED } \\
\hline $\mathbf{1}$ & $\mathbf{2}$ & $\mathbf{3}$ & $\mathbf{4}$ & $\mathbf{5}$ \\
\hline Not Important & Little Important & Indifferent & Important & Very Important \\
\hline
\end{tabular}

Table 10. Degree of importance, in the perception of the managers of TBIs, of the entrepreneurial characteristics (part 1).

\begin{tabular}{|c|c|c|c|c|c|c|}
\hline \multirow{2}{*}{$\begin{array}{l}\text { Entrepreneurial } \\
\text { characteristics }\end{array}$} & \multirow{2}{*}{$\begin{array}{c}\text { Number } \\
\text { of TBIs } \\
\text { respondents }\end{array}$} & \multicolumn{5}{|c|}{ Degree of Importance } \\
\hline & & 1 & 2 & 3 & 4 & 5 \\
\hline Innovative & 5 & - & - & - & 1 & 4 \\
\hline Leader & 5 & - & - & - & 3 & 2 \\
\hline Assumes Risks & 5 & - & - & - & 2 & 3 \\
\hline Independent & 5 & - & - & 1 & 2 & 2 \\
\hline Creative & 5 & - & - & - & 1 & 4 \\
\hline Own initiative & 5 & - & - & - & 2 & 3 \\
\hline Persevering & 5 & - & - & - & 3 & 2 \\
\hline Persistent & 5 & - & - & - & 2 & 3 \\
\hline Willing to learn & 5 & - & - & - & 3 & 2 \\
\hline $\begin{array}{l}\text { Identified with new } \\
\text { business opportunities }\end{array}$ & 5 & - & - & 1 & 4 & - \\
\hline Decision maker & 5 & - & - & - & 1 & 4 \\
\hline Can work in groups & 3 & - & - & - & 2 & 1 \\
\hline It has systemic vision & 3 & - & - & - & 2 & 1 \\
\hline
\end{tabular}


Table 11. Degree of importance given, in the perception of TBIs managers, to the resources offered by TBIs (part 2).

\begin{tabular}{|c|c|c|c|c|c|c|}
\hline \multirow{2}{*}{ Resources offered by TBIs } & \multirow{2}{*}{$\begin{array}{l}\text { Number of TBIs } \\
\text { respondents }\end{array}$} & \multicolumn{5}{|c|}{ Degree of Importance } \\
\hline & & 1 & 2 & 3 & 4 & 5 \\
\hline Access to laboratories (high-precision or high-cost equipment) & 5 & - & 1 & - & 2 & 2 \\
\hline Library access & 5 & - & - & 1 & 3 & 1 \\
\hline Using the module & 5 & - & - & & 3 & 2 \\
\hline $\begin{array}{l}\text { Availability of facilities infrastructure (meeting room, cafeteria, } \\
\text { toilets, among others) }\end{array}$ & 5 & - & - & - & 3 & 2 \\
\hline $\begin{array}{l}\text { Availability of communication services infrastructure (telephone, } \\
\text { fax, Internet, computers, among others) }\end{array}$ & 5 & - & - & - & 3 & 2 \\
\hline $\begin{array}{l}\text { Existence of advisory services through consultants (accountant, } \\
\text { lawyer, administrator, engineer, financier, etc.) }\end{array}$ & 5 & - & - & - & 2 & 3 \\
\hline Participation of university researchers (teachers and students) & 5 & - & - & 1 & 1 & 3 \\
\hline $\begin{array}{l}\text { Participation of owners (entrepreneurs) in events (seminars, fairs, } \\
\text { courses etc.) }\end{array}$ & 5 & - & - & - & 1 & 4 \\
\hline Business and management support services & 5 & - & - & - & 2 & 3 \\
\hline Support services for technological training & 5 & - & - & - & 1 & 4 \\
\hline
\end{tabular}

Table 12. Degree of importance of resources offered in partnerships with other development agents in the perception of managers of TBIs (part 3).

\begin{tabular}{|c|c|c|c|c|c|c|}
\hline \multirow{2}{*}{$\begin{array}{l}\text { Resources offered in partnerships with } \\
\text { other development agents }\end{array}$} & \multirow{2}{*}{$\begin{array}{l}\text { Number of TBIs } \\
\text { respondents }\end{array}$} & \multicolumn{5}{|c|}{ Degree of Importance } \\
\hline & & 1 & 2 & 3 & 4 & 5 \\
\hline Partnership with universities & 5 & - & - & - & 2 & 3 \\
\hline Partnership with research centers and R\&D institutes & 5 & - & - & - & 3 & 2 \\
\hline Support of the National Program to Support the Business Incubator & 5 & - & - & - & 1 & 4 \\
\hline $\begin{array}{l}\text { Support for Human Resource Capacity Building Programs for } \\
\text { Strategic Activities }\end{array}$ & 5 & - & - & - & 2 & 3 \\
\hline Support for Micro and Small Business Technology Support Programs & 5 & - & - & - & 1 & 4 \\
\hline Support from SEBRAE Consulting through Programs offered & 5 & - & - & 1 & 3 & 1 \\
\hline Support of the Inovar Project to provide funding & 5 & - & - & - & 1 & 4 \\
\hline Support of the Brazil Entrepreneurial Training Program & 5 & - & - & 1 & 2 & 2 \\
\hline $\begin{array}{l}\text { Support from Financial Agents (Banco do Brasil, Caixa Econômica } \\
\text { Federal, Banco do Empreendedor etc.) }\end{array}$ & 5 & - & - & 1 & 2 & 2 \\
\hline Access to the programs made available by CNPq, FAPESP, etc. & 5 & - & - & - & 1 & 4 \\
\hline
\end{tabular}

Table 13. Degree of importance, in the perception of the managers of TBIs, of the selection requirements by TBIs (part 4).

\begin{tabular}{|c|c|c|c|c|c|c|}
\hline \multirow{2}{*}{ Selection requirements by TBIs } & \multirow{2}{*}{$\begin{array}{c}\text { Number of TBIs } \\
\text { respondents }\end{array}$} & \multicolumn{5}{|c|}{ Degree of Importance } \\
\hline & & 1 & 2 & 3 & 4 & 5 \\
\hline $\begin{array}{l}\text { Requirement of a product or service with technical and economic } \\
\text { feasibility }\end{array}$ & 5 & - & - & - & 1 & 4 \\
\hline Demand for product or service with innovative features & 5 & - & - & - & - & 5 \\
\hline Technical qualification of the owner (s) & 5 & - & - & 1 & - & 4 \\
\hline Management skill of the owner (s)) & 5 & - & - & - & 3 & 2 \\
\hline Profile of owner (s) and team & 5 & - & - & 1 & 2 & 2 \\
\hline Sector of activity of the enterprise & 5 & - & - & - & 1 & 4 \\
\hline Experience of the owner (s) in the sector of performance & 5 & - & - & - & 2 & 3 \\
\hline Possibility of generating new jobs & 5 & - & - & - & 3 & 2 \\
\hline Possible contribution to the region's economic development & 5 & - & - & - & 3 & 2 \\
\hline Possibility of interaction with universities or research centers & 5 & - & - & - & 1 & 4 \\
\hline Possible financial return of the development & 5 & - & - & - & 1 & 4 \\
\hline Use of a non-polluting or low-polluting production process & 5 & - & - & - & 2 & 3 \\
\hline Sustainability of the project presented by incubated & 5 & - & - & - & - & 5 \\
\hline
\end{tabular}


Table 14. Degree of importance, in the perception of the TBF managers, of the entrepreneurial characteristics (part 1).

\begin{tabular}{lcccccc}
\hline \multirow{2}{*}{ Entrepreneurial characteristics } & Number of TBFs & \multicolumn{5}{c}{ Degree of Importance } \\
\cline { 3 - 7 } & respondents & $\mathbf{1}$ & $\mathbf{2}$ & $\mathbf{3}$ & $\mathbf{4}$ & $\mathbf{5}$ \\
\hline Innovation & 25 & - & - & - & 9 & 16 \\
Leadership & 25 & 1 & - & 2 & 15 & 7 \\
Accept risks & 25 & - & - & 5 & 13 & 7 \\
Independence & 25 & 1 & - & 5 & 11 & 8 \\
Creativity & 25 & - & 1 & 4 & 5 & 15 \\
Initiative & 25 & - & - & 1 & 13 & 11 \\
Perseverançe & 25 & - & - & 1 & 7 & 17 \\
Persistence & 25 & - & - & 3 & 6 & 16 \\
Owner's Learning Layout & 25 & - & 1 & 1 & 6 & 17 \\
Identification of new business opportunities & 25 & - & - & 4 & 4 & 17 \\
Decision-making & 25 & - & - & 2 & 9 & 14 \\
\hline
\end{tabular}

Table 15. Degree of importance, in the perception of TBF managers, of the resources offered by TBIs (part 2).

\begin{tabular}{|c|c|c|c|c|c|c|}
\hline \multirow[b]{2}{*}{ Resources offered by TBIs } & \multirow{2}{*}{$\begin{array}{c}\text { Number } \\
\text { of TBFs } \\
\text { respondents }\end{array}$} & \multicolumn{5}{|c|}{ Degree of Importance } \\
\hline & & 1 & 2 & 3 & 4 & 5 \\
\hline Access to laboratories (high-precision or high-cost equipment) & 21 & 2 & 2 & 7 & 2 & 8 \\
\hline Library access & 25 & 3 & 2 & 9 & 5 & 6 \\
\hline Using the module & 24 & 1 & 1 & 3 & 9 & 10 \\
\hline $\begin{array}{l}\text { Availability of facilities infrastructure (meeting room, cafeteria, toilets, } \\
\text { among others) }\end{array}$ & 25 & - & - & 2 & 8 & 15 \\
\hline $\begin{array}{l}\text { Availability of communication services infrastructure (telephone, fax, } \\
\text { Internet, computers, among others) }\end{array}$ & 25 & - & 1 & 2 & 9 & 13 \\
\hline $\begin{array}{l}\text { Existence of advisory and consulting services (accountant, lawyer, } \\
\text { administrator, engineer, financier, etc.) }\end{array}$ & 25 & 1 & - & 6 & 8 & 10 \\
\hline Participation of university researchers (teachers and students) & 20 & - & 3 & 8 & 5 & 4 \\
\hline Participation of owners in events (seminars, congresses, fairs, courses etc.) & 25 & 1 & - & 3 & 7 & 14 \\
\hline Business and management support services & 25 & 1 & - & 1 & 12 & 11 \\
\hline Support services for technological training & 25 & 2 & - & 5 & 7 & 11 \\
\hline
\end{tabular}

Table 16. Degree of importance, in the perception of TBF managers, of the resources offered in partnerships with other development agents (part 3).

\begin{tabular}{lcccccc}
\hline Resources offered in partnerships with other development agents & \multicolumn{2}{c}{$\begin{array}{c}\text { Number } \\
\text { of TBFs } \\
\text { respondents }\end{array}$} & \multicolumn{1}{c}{ Degree of Importance } \\
\cline { 3 - 7 } & $\mathbf{1}$ & $\mathbf{2}$ & $\mathbf{3}$ & $\mathbf{4}$ & $\mathbf{5}$ \\
\hline Partnership with universities & 21 & 1 & 2 & 8 & 9 & 5 \\
Partnership with research centers and R\&D institutes & 1 & 2 & 6 & 3 & 9 \\
Support of the National Program to Support the Business Incubator & 25 & 2 & - & 6 & 13 & 4 \\
Support for Human Resource Capacity Building Programs for Strategic & 25 & 2 & 2 & 5 & 10 & 6 \\
Activities & & & & & \\
Support for Micro and Small Business Technology Support Programs & 21 & 1 & - & 5 & 7 & 8 \\
SEBRAE Consulting through Programs offered & 25 & - & 3 & 2 & 10 & 10 \\
Access to the Inovar Project to provide financing & 25 & 3 & 2 & 6 & 8 & 6 \\
Support of the Brazil Entrepreneurial Training Program & 25 & 3 & 4 & 9 & 4 & 5 \\
Support from Financial Agents (Banco do Brasil, Caixa Econômica & 25 & 5 & 5 & 9 & 2 & 4 \\
Federal, Banco do Empreendedor etc.) & & & & & & \\
Access to the programs made available by CNPq, FAPESP, etc. & 23 & 2 & 2 & 2 & 8 & 9 \\
\hline
\end{tabular}


Table 17. Degree of importance, in the perception of the TBF managers, of the selection requirements by the TBIs (part 4).

\begin{tabular}{|c|c|c|c|c|c|c|}
\hline \multirow[b]{2}{*}{ Selection requirements by TBIs } & \multirow{2}{*}{$\begin{array}{c}\text { Number } \\
\text { of TBFs } \\
\text { respondents }\end{array}$} & \multicolumn{5}{|c|}{ Degree of Importance } \\
\hline & & 1 & 2 & 3 & 4 & 5 \\
\hline $\begin{array}{l}\text { Requirement of a product or service with technical and economic } \\
\text { feasibility }\end{array}$ & 25 & 1 & - & 1 & 8 & 15 \\
\hline Demand for product or service with innovative features & 25 & 2 & - & 2 & 12 & 9 \\
\hline Technical capacity of the owner (s) & 25 & 1 & - & 5 & 7 & 12 \\
\hline Management skill of the owner (s) & 25 & 1 & 1 & 11 & 9 & 3 \\
\hline Profile of owner (s) and team & 25 & 1 & - & 7 & 16 & 1 \\
\hline Sector of activity of the enterprise & 25 & 2 & 2 & 6 & 4 & 11 \\
\hline Experience of the owner (s) in the sector of performance & 25 & 1 & - & 6 & 10 & 8 \\
\hline Possibility of generating new jobs & 25 & 2 & 4 & 1 & 7 & 11 \\
\hline Possible contribution to the region's economic development & 25 & 1 & 2 & 3 & 8 & 11 \\
\hline Possibility of interaction with universities or research centers & 25 & 4 & 2 & 9 & 5 & 5 \\
\hline Possible financial return of the development & 25 & - & - & 3 & 8 & 14 \\
\hline Use of a non-polluting or low-polluting production process & 25 & 2 & 3 & 3 & 7 & 10 \\
\hline Sustainability of the project presented by incubated & 25 & 1 & 2 & 2 & 9 & 11 \\
\hline
\end{tabular}

\subsection{Degree of importance in the perception of TBIs managers}

In Table 10, the degree of importance of the entrepreneurial characteristics (part 1) can be verified in the perception of TBI managers.

Table 11 shows the importance of the resources offered by TBIs (part 2) in the perception of TBIs managers.

In Table 12, the degree of importance, according to TBI managers' perception, of the resources offered in partnerships with other development agents (part 3) can be verified.

Regarding Table 13, the degree of importance of TBI managers' perception of the selection requirements by the TBIs (part 4) is verified.

\subsection{Degree of importance in the perception of TBFs managers}

Table 14 shows the degree of importance, in the perception of the managers of TBFs, of entrepreneurial characteristics (part 1).

Table 15 shows the degree of importance, in the perception of TBF managers, of the resources offered by the TBIs (part 2).

In Table 16, it is possible to verify the degree of importance of the resources offered in partnerships with other development agents according to the perception of the TBF managers (part 3).

Table 17 shows the degree of importance, in the perception of the TBF managers, of the selection requirements by the TBIs (part 4).

\section{Discussion of results}

In this section, we present the analysis and discussion of the results, from the application of the questionnaires:
- Technical support services, the demand for products or services with innovative characteristics, the sustainability of the project, the technical and economic feasibility of the product or service were considered very important by the managers;

- In the incubation period, TBF managers should be encouraged to learn, a basic condition for relating knowledge with management practices;

- The resources used by TBI managers, in favor of TBFs, are a source of competitive advantage, provided they are used as a business strategy tool;

- Innovation, creativity, decision making, identifying opportunities, initiative, perseverance, teamwork and systemic vision are characteristics considered in the profile of an entrepreneur;

- The low cost of information, knowledge and services obtained during the incubation period is fundamental to the success of TBF;

- Access to laboratories, library use and the involvement of universities in the use of laboratories were considered important by managers;

- The installation infrastructure and the communication services were considered relevant;

- The sector of activity of the enterprise and the financial return were also considered important;

- SEBRAE's participation was considered important, even if it was removed from the incubators of the state of São Paulo in 2010 due to labor 
problems, which resulted in the suspension of its activities at the time. The situation was still unresolved when this research was carried out.

This work did not aim to compare the responses of the managers of the TBIs and the TBFs, due to the difference in the sample size and the distinct nature of the respondents, however, some disparities were observed and deserve registration, so they are related, below:

- Managers of TBIs were more concerned about products or services with innovative features than managers of TBFs;

- Most TBI managers considered the contribution factor "a requirement for a product or service with technical and economic feasibility" very important for an TBF. However, TBF managers did not consider this factor as essential to the success of the venture;

- TBI managers evaluated the sustainability contribution factor of the project presented by the company as very important for an TBF. However, TBF managers did not consider this primary factor;

- The support of financial agents (Banco do Brasil, Caixa Econômica Federal, Banco do Empreendedor, etc.) was considered important for managers of TBIs, which was not the case for managers of TBFs. The low value given by the TBF managers originates in the difficulty of access to financing, due to the bureaucracy, that is, this difficulty is greater for the TBFs because they are considered high risk businesses;

- The support of the Brazil Entrepreneurship Program for Business Training, aimed at strengthening small enterprises in the informal sector, and the Human Resources Training Program for Strategic Activities, were more relevant in the view of TBI managers, because the bureaucracy factor can have contributed, again, to the low relevance given by TBFs managers;

- The Inovar Project for the provision of financing was considered important in the view of TBI managers, different from the perception of TBF managers, perhaps due to the difficulty in obtaining financial resources from the Federal Government. Here too the bureaucracy can be considered to be responsible for the low relevance given by TBFS managers;
- The managerial ability of the owner (s) had greater relevance in the view of the managers of TBIs and was considered less important in the perception of the managers of the TBFs. Most TBF managers are students and scientists with a technical profile, which may lead to disregarding the importance of managerial ability.

\section{Conclusion}

The degree of importance perceived by the managers of incubators and technology-based companies in the Vale do Paraíba Paulista region in relation to the following factors was analyzed: entrepreneurial characteristics; resources offered by TBIs; resources offered in partnerships with other development agents and requirements for selection of TBFs by the TBIs.

The realization of this survey made it possible to verify how technology-based entrepreneurship was practiced in the VPP region in 2011 by presenting important information from the region. In addition, it made possible to analyze the perception of the managers of TBIs and TBFs on the considered factors.

According to the managers of TBIs, the factors considered were fundamental for the development of an TBF. This can be verified by assigning to the questions degree of importance with a higher concentration between four and five.

In the perception of TBFs managers, the distribution of degrees of importance ranged from one to five, and in some cases considered very important, the variation was from one to three. The technical training of such managers may justify such distribution.

TBIs and TBFs readily agreed to participate in the research and the period of contact with them was productive, but some difficulties were encountered during this process, for example access to TBIs that were in restricted areas of government; the difficulty of contacting some managers and the delay on the part of some managers to deliver the questionnaires answered.

It was also considered as a limitation for the development of this research the number of managers of TBIs (5) and of TBFs (25) participants, since although it was possible to make a survey of their perception regarding the analyzed factors, the use of a more robust statistical analysis was made unfeasible.

The studies carried out do not intend to end with the subject matter here; on the contrary, we sought to make a contribution with this research. In addition, it is proposed as a continuity the application of questionnaires in other regions that concentrate TBIs and TBFs and also in other types of incubators and incubators. 


\section{References}

Associação Nacional de Entidades Promotoras de Tecnologias Avançadas - ANPROTEC. (2002). Glossário dinâmico de termos na área de tecnópoles, parques tecnológicos e incubadoras de empresas (1. ed.). Brasília: ANPROTEC/ SEBRAE.

Associação Nacional de Entidades Promotoras de Tecnologias Avançadas - ANPROTEC. (2010). Brasília: ANPROTEC. Retrieved in 2010, March 16, from www.anprotec.com.br

Berté, E. C. O. P., \& Almeida, M. I. R. (2006). Contribuição ao processo de formulação estratégica em pequenas empresas de base tecnológica - PTBC's. In Anais do Encontro Luso-brasileiro de Estratégia. Balneário Camboriú: SLADE.

Cooper, S. Y., \& Park, J. S. (2008). The impact of 'incubator' organizations on opportunity recognition and techology innovation in new, entrepreneurial high-technology ventures. International Small Business Journal, 26(1), 27-56. http://dx.doi.org/10.1177/0266242607084658.

Filion, L. J. (1999). Diferenças entre sistemas gerenciais de empreendedores e operadores de pequenas negócios. Revista de Administração de Empresas, 39(4), 6-20. http://dx.doi.org/10.1590/S0034-75901999000400002.

Gil, A. C. (2002). Como elaborar projetos de pesquisa (4. ed.). São Paulo: Atlas.

Instituto Brasileiro de Geografia e Estatística - IBGE. (2011). Perfil dos municípios brasileiros. Rio de Janeiro. Retrieved in 2012, March 19, from http://www.ibge. gov.br/home/estatistica/economia/perfilmunic/2011/ default.shtm

Likert, R. A. (1932). Technique for the measurement of attitudes. Archives de Psychologie, 140, 1-55.

Macêdo, F. M. F., Ichikawa, E. Y., \& Boava, D. L. T. (2009). Estudo sobre o empreendedorismo na Incubadora Tecnológica de Maringá a partir da fenomenologia social. In Anais do XXIX Encontro Nacional de Engenharia de Produção. Salvador: ABEPRO.

Melo, H. S., \& Leitão, L. C. (2010). Dicionário tecnologia e inovação (1. ed.). Fortaleza: Serviço de Apoio as Micro e Pequenas Empresas do Estado do Ceará.

Paletta, F. C. (2008). Tecnologia da informação, inovação e empreendedorismo: fatores críticos de sucesso no uso de ferramentas de gestão em empresas incubadas de base tecnológica (Tese de doutorado). Instituto de Pesquisa Energéticas e Nucleares, Universidade de São Paulo, São Paulo.

Pereira, M. F., Grapeggia, M., Emmendoerfer, M. L., \& Três, D. L. (2009). Fatores de inovação para a sobrevivência das micro e pequenas empresas no Brasil. Revista de Administração e Inovação, 6(1), 50-65.

Pinho, M., Côrtes, M. R., \& Fernandes, A. C. (2002). A fragilidade das empresas de base tecnológica em economias periféricas: uma interpretação baseada na experiência brasileira. Revista Ensaios FEE, 23(1), 135-162.

Porton, R. A. B., \& Longary, A. A. (2005). Análise das características empreendedoras dos criadores de empresas de base tecnológica instaladas na incubadora CELTA/ SC. In Anais do XXV Encontro Nacional de Engenharia de Produção. Porto Alegre: ABEPRO.

Raupp, F. M., \& Beuren, I. M. (2009). Programas oferecidos pelas incubadoras brasileiras às empresas incubadas. Revista de Administração e Inovação, 6(1), 83-107.

Remiro, M. S. L., Oliveira, R. T. Q., Melo, J. M. C., \& Araújo, L. R. (2008). O papel da incubadora de empresas no processo de transferência de conhecimento/tecnologia: o caso da Universidade Federal Fluminense. In Anais do IV Congresso Nacional de Excelência em Gestão. Rio de Janeiro CNEG.

Santos, D. T., \& Pinho, M. (2010). Análise do crescimento das empresas de base tecnológica no Brasil. Produção, 20(2), 214-223. http://dx.doi.org/10.1590/S010365132010005000027.

Serviço Brasileiro de Apoio às Micro e Pequena Empresas - SEBRAE. (2006). Onde estão as micro e pequenas empresas no Brasil (1. ed.). São Paulo: SEBRAE.

Silva, S. L., Toledo, J. C., Mendes, G. H. S., \& Jugend, D. (2005). Fatores críticos de sucesso no desenvolvimento de produtos: comparações entre empresas brasileiras de base tecnológica. In Anais do XXIII Encontro Nacional de Engenharia de Produção. Fortaleza: ABEPRO.

Stainsack, C. (2003). Estrutura, organização e gestão de incubadoras tecnológicas (Dissertação de mestrado). Programa de Pós-graduação em Tecnologia, Centro Federal de Educação Tecnológica do Paraná, Curitiba.

Toledo, J. C., Silva, S. L., Mendes, G. H. S., \& Jugend, D. (2008). Fatores críticos de sucesso no gerenciamento de projetos de desenvolvimento de produto em empresas de base tecnológica de pequeno e médio porte. Revista Gestão e Produção, 15(1), 117-134. http://dx.doi. org/10.1590/S0104-530X2008000100011.

Torkomian, A. L. V., \& Piekarski, A. E. T. (2008). Gestão da tecnologia. In M. O. Batalha (Ed.), Introdução à Engenharia de Produção (1. ed.). Rio de Janeiro: Elsevier.

Vale do Paraíba Paulista. (2012). Divisão política. Retrieved in 2012, August 5, from http://www.valedoparaiba.com/ terragente/bancodedados/mapa_vale.htm

Yin, R. K. (2006). Estudo de caso: planejamento e métodos (D. Grassi \& C. Damacena, Trad., 2. ed.). Porto Alegre: Bookman.

Zica, R. M., \& Martins, H. C. (2008). Sistema de garantia de crédito para micro e pequenas empresas no Brasil: proposta de um modelo. Revista de Administração Pública, 42(1), 181-204. http://dx.doi.org/10.1590/ S0034-76122008000100009. 
Appendix A. Questionnaire applied to TBFs managers.

\begin{tabular}{|c|c|c|c|c|c|}
\hline Entrepreneurial characteristics (part 1) & \multicolumn{5}{|c|}{ Degree of Importance } \\
\hline Innovation & 1 & 2 & 3 & 4 & 5 \\
\hline Leadership & 1 & 2 & 3 & 4 & 5 \\
\hline Accept risks & 1 & 2 & 3 & 4 & 5 \\
\hline Independence & 1 & 2 & 3 & 4 & 5 \\
\hline Creativity & 1 & 2 & 3 & 4 & 5 \\
\hline Initiative & 1 & 2 & 3 & 4 & 5 \\
\hline Perseverance & 1 & 2 & 3 & 4 & 5 \\
\hline Persistence & 1 & 2 & 3 & 4 & 5 \\
\hline Owner's Learning Layout & 1 & 2 & 3 & 4 & 5 \\
\hline Identification of new business opportunities & 1 & 2 & 3 & 4 & 5 \\
\hline Decision-making & 1 & 2 & 3 & 4 & 5 \\
\hline Resources offered by TBIs (part 2) & \multicolumn{5}{|c|}{ Degree of Importance } \\
\hline Access to laboratories (high-precision or high-cost equipment) & 1 & 2 & 3 & 4 & 5 \\
\hline Library access & 1 & 2 & 3 & 4 & 5 \\
\hline Using the module & 1 & 2 & 3 & 4 & 5 \\
\hline $\begin{array}{l}\text { Availability of facilities infrastructure (meeting room, cafeteria, toilets, among } \\
\text { others) }\end{array}$ & 1 & 2 & 3 & 4 & 5 \\
\hline $\begin{array}{l}\text { Availability of communication services infrastructure (telephone, fax, Internet, } \\
\text { computers, among others) }\end{array}$ & 1 & 2 & 3 & 4 & 5 \\
\hline $\begin{array}{l}\text { Existence of advisory and consulting services (accountant, lawyer, administrator, } \\
\text { engineer, financier, etc.) }\end{array}$ & 1 & 2 & 3 & 4 & 5 \\
\hline Participation of university researchers (teachers and students) & 1 & 2 & 3 & 4 & 5 \\
\hline Participation of owners in events (seminars, congresses, fairs, courses etc.) & 1 & 2 & 3 & 4 & 5 \\
\hline Business and management support services & 1 & 2 & 3 & 4 & 5 \\
\hline Support services for technological training & 1 & 2 & 3 & 4 & 5 \\
\hline
\end{tabular}

\begin{tabular}{|c|c|c|c|c|c|}
\hline Resources offered in partnerships with other development agents (part 3) & \multicolumn{5}{|c|}{ Degree of Importance } \\
\hline Partnership with universities & 1 & 2 & 3 & 4 & 5 \\
\hline Partnership with research centers and R \& D institutes & 1 & 2 & 3 & 4 & 5 \\
\hline Support of the National Program to Support the Business Incubator & 1 & 2 & 3 & 4 & 5 \\
\hline Support for Human Resource Capacity Building Programs for Strategic Activities & 1 & 2 & 3 & 4 & 5 \\
\hline Support for Micro and Small Business Technology Support Programs & 1 & 2 & 3 & 4 & 5 \\
\hline SEBRAE Consulting through Programs offered & 1 & 2 & 3 & 4 & 5 \\
\hline Access to the Inovar Project to provide financing & 1 & 2 & 3 & 4 & 5 \\
\hline Support of the Brazil Entrepreneurial Training Program & 1 & 2 & 3 & 4 & 5 \\
\hline $\begin{array}{l}\text { Support from Financial Agents (Banco do Brasil, Caixa Econômica Federal, Banco } \\
\text { do Empreendedor etc.) }\end{array}$ & 1 & 2 & 3 & 4 & 5 \\
\hline Access to programs provided by CNPq, FAPESP, among others & 1 & 2 & 3 & 4 & 5 \\
\hline
\end{tabular}

\begin{tabular}{|c|c|c|c|c|c|}
\hline \multicolumn{6}{|l|}{ Access to programs provided by CNPq, FAPESP, among others } \\
\hline Requirements for selection of TBFs by TBIs (part 4) & \multicolumn{5}{|c|}{ Degree of Importance } \\
\hline Requirement of a product or service with technical and economic feasibility & 1 & 2 & 3 & 4 & 5 \\
\hline Demand for product or service with innovative features & 1 & 2 & 3 & 4 & 5 \\
\hline Technical capacity of the owner (s) & 1 & 2 & 3 & 4 & 5 \\
\hline Management skill of the owner (s) & 1 & 2 & 3 & 4 & 5 \\
\hline Profile of owner (s) and team & 1 & 2 & 3 & 4 & 5 \\
\hline Sector of activity of the enterprise & 1 & 2 & 3 & 4 & 5 \\
\hline Experience of the owner (s) in the sector of performance & 1 & 2 & 3 & 4 & 5 \\
\hline Possibility of generating new jobs & 1 & 2 & 3 & 4 & 5 \\
\hline Possible contribution to the region's economic development & 1 & 2 & 3 & 4 & 5 \\
\hline Possibility of interaction with universities or research centers & 1 & 2 & 3 & 4 & 5 \\
\hline Possible financial return of the development & 1 & 2 & 3 & 4 & 5 \\
\hline Use of a non-polluting or low-polluting production process & 1 & 2 & 3 & 4 & 5 \\
\hline Sustainability of the project presented by incubated & 1 & 2 & 3 & 4 & 5 \\
\hline
\end{tabular}

